\title{
Redesigning an Auditing Course to Develop Technology Competence
}

\author{
Diana Tien Irafahmi ${ }^{*}$ P John Williams ${ }^{2}$ Rosemary Kerr ${ }^{3}$ \\ ${ }^{1}$ Universitas Negeri Malang \\ ${ }^{1,2,3}$ Curtin University \\ Corresponding author.Email:_dianatien.irafahmi@postgrad.curtin.edu.au
}

\begin{abstract}
Incorporating technology into an auditing curriculum is an ongoing challenge for accounting and auditing educators. This study examined the effect of an intervention to develop technology competence. The intervention involved redesigning a course on the basis of Constructive Alignment (CA). The primary intention of CA is to better align three elements in course design: the Intended Learning Outcomes (ILO), the Teaching and Learning Activities (TLA), and the Assessment Tasks (AT). Through case-based learning as the main TLA and AT, students practiced using Excel to complete electronic audit documentations. We focused on the research question: Does redesigning the auditing course using CA lead to improve students' competence in technology? A quantitative and qualitative design was adopted, using a pre-post-test and interview. Our findings suggest redesigning the course in this way improve technology competence and educators should consider students' expectation to work on more specialized audit software.
\end{abstract}

Keywords: auditing course, constructive alignment, technology competence, auditing education, accounting education

\section{INTRODUCTION}

The Public accounting profession has a tight relationship with the use of technology $[1,2]$. While the need for incorporating technology into auditing curriculum has been a major call from accounting bodies $[3,4,5]$, limited guidance is available to assist educators in determining how to use technology in auditing classes. In this study, guided by Biggs' Constructive Alignment framework [6, 7, 8, 9], we show how students' technological competence can be developed by redesigning the course system. Rather than focusing attention on the 'what' of technology that was frequently examined in prior studies [e.g. 10,11,12,13], the study put emphasis on the 'how' aspect of course design.

The results of this study should be of interest to both academics and researchers. The study provides a clear guideline for accounting academics to include technology in the curriculum with the ultimate goal to equip students with relevant competencies for their future careers. The study is also important for researchers because it provides evidence that changing the course design using an outcomes based approach significantly contributes to the development of students' competence.

\section{LITERATURE REVIEW}

Information technology has been recognized as an essential tool to make audits more efficient and effective $[1,2,11]$. In an interview with a panel of Certified Public Accountants (CPA), Drew [14] asked which skills are important for CPA's. The panel suggested that technological literacy is the key to stay on top of the profession along with communication and thinking skills [14]. The usage of technology by audit firms is quite intensive at all stages of the audit [2]. The dominant usages of technology are especially in the stages of audit planning, audit testing and audit documentation [2]. Technology helps auditors in the planning stage of an audit to assess the external and internal risk in the business process of the clients that affect the audit [2]. In the stage of audit testing, technology reduces the time to complete audit procedures, such as recalculation, identifying unusual transactions, selecting samples, and extracting data, which previously were handled manually [2]. Further, technology has replaced the form of audit documentation, from paper into electronic documentation. The advantages of paperless documentation are shareable and manageable among auditors over years [2]. 
Given the substantial role of technology in the accounting workplaces, standard setter and accounting bodies encourage accounting educators to infuse technological competence across the accounting curriculum. Through a new accreditation standard, standard A5, The Association to Advance Collegiate Schools of Business (AACSB) as an accreditation body put emphasis on developing students' agility with technology [3]. The term 'agility' refers to the ability to quickly adapt and use new technology without extended training [1]. Accounting departments seeking AACSB accreditation now have to document the learning strategies deployed in each course to improve students' technological competence and list the types of technology used in each course to support students' learning, not including presentation software and word processing [3]. The AICPA pre-certification core competency framework also identifies technological competence as the core competencies that have long term value for future accounting professionals [4]. Within the AICPA core competency framework, students have to be able to identify and use appropriate technologies that can help them to perform well on accounting or auditing tasks [4]. The International Accounting Education Standard Board (IAESB) also recognizes the importance of leveraging technology for accounting students [5]. Accounting graduates should demonstrate proficiency in information technology, as indicated by the ability to explain the role of technology as well as to utilize relevant technologies to support business decision making [5].

Amongst the many auditing software available in the market, general spreadsheet software Microsoft Excel continues to show its dominance. Literature indicates that auditors use Excel very frequently on their daily working activities $[11,13,16,17,18,19,20]$. The dominance of Excel is not limited to public accounting, Excel has been used across different accounting areas [18], such as in managerial accounting [21, 22], financial reporting [23, 24], and public accounting sector [11, 13, 17, 18]. As such, Excel should be incorporated into the accounting curriculum [18].

Although accounting educators understand that Excel is prominent for the profession and there is a need to improve students' technological competency in the university [12], exposure to technology in university is still considered insufficient $[12,13,23]$. A survey on accounting academics at more than 100 accounting programs in the US found that students lack in Excel skills, based on faculty's perception [12]. This finding is similar to a study [23] that discovered alumni and accounting firms complaints about accounting graduates' inability to use excel in a professional work setting. A disconnection between students' perception and new hires' perception of the Excel function that is useful for a job in public accounting was also found in another study [13]. Students underestimated several functions in Excel that are frequently used by auditors [14], indicating the strategies to infuse technology in accounting program needs development.

Incorporating technology into the auditing curriculum is challenging, in part due to the already large coverage of topics in syllabus [20, 25, 26], the function and type of technology that continues to evolve, and the lack of reward for educators who make substantial work on curriculum development [18, 27].

Recent initiatives to close the technology gap include the development of instructional cases to teach Excel to students $[20,23,28]$. These initiatives, however, focus on teaching students to learn Excel in Accounting Information Systems and focus less on how Excel can be adopted to facilitate the work of auditors. Some useful examples in the literature [e.g., 29, 30, 31, 32] embrace Excel in the development of auditing instructional cases and indicate that Excel can be integrated within the auditing topic through the use of case-based learning. While case-based learning is a useful method to bring real world auditing to students, it is however only one method within the whole course design. Biggs [6] reminds us that to develop students' competence, we need to address the system as a whole. Several researchers [33, 34] support Biggs' contention and specify several steps to address the whole approach, including setting learning outcomes for the course and creating teaching learning activities and assessment that in line with the learning outcomes. The idea to design a course using an outcomes-based approach matches an established framework in higher education literature: Constructive Alignment.

Constructive Alignment is a form of outcomes-based approach that addresses the quality of teaching and learning [9]. Although variously named, the basic concept of Constructive Alignment has been reinforced in the accounting education literature [33, 34, 35, 36]. In an outcomes-based approach, the focus is on students' outcomes after having been taught on certain topics that relevant to achieve the outcomes [9]. To help students develop a particular learning outcome, the design of each course should be improved [9]. The key to improving the course design is to define the learning outcomes and create meaningful learning activities and assessments that support the learning outcomes $[8,9]$.

The most problematic issue with the course design in accounting education is that it is excessively content driven [37], which can inhibit the development of a graduate attribute such as technology competence. A preliminary assignment to the auditing syllabus in the present study justifies this problem. The outcomes, teaching activities, and assessment tasks emphasis declarative knowledge and lack of alignment. In addition, learning outcomes do not specify that students are expected to achieve technology competence. Therefore, the present study attempts to explore the impact of redesigning an auditing course using Constructive 
Alignment in order to assist students in developing technology competence. The study addresses the following question: Does redesigning the auditing course using CA lead to improved students' competence in technology?

\section{COURSE REDESIGN}

In redesigning the auditing course, the research followed the detailed guidelines of Constructive Alignment. The researchers analysed the syllabus of an Auditing course, and a lack of alignment was discovered; there was also no expectation for students to achieve 'technology competence' in the learning outcomes. In collaboration with the auditing instructor, the course was redesigned through several steps.

In Step 1, we added a technology competence requirement in the ILO, guided by the learning outcomes in IAESB [38]: "Upon completion of this course, students should be able to use information technology (Excel) to support decision making in an audit engagement". The ILO addresses functioning knowledge, a type of knowledge that professionals concern with [9].

In Step 2, we created TLAs that support the ILO. Because we wanted students to use real world problems in auditing while incorporating technology, we decided to apply case-based learning as the main TLA. A study [39] that surveyed professors of accounting programs in the US found that case study is the most assigned activity in their courses. By applying case-based learning, students are expected to develop and apply their knowledge through 'just-in-time learning' [9]. We carefully selected the cases that meet two criteria: incorporating the use of Excel within the case, and relevance to the auditing topic in each particular week. We picked the cases mostly from a journal of 'Issues in Accounting Education'. Because the case-based learning may require a longer time to complete, students were encouraged to read the case and learn the concept before the class.

In Step 3, we created assessment tasks (AT) that enabled judgments as to how well a student's level of performance meets the ILO [9]. There are two types of assessment, formative and summative. We used weekly case studies feedback as a formative assessment. Whereas for the summative assessment we used a prepost test case study adapted from Andiola et al. [32]. The alignment between the main components of the system is depicted in Table 1. Biggs and Tang [9] assert that when "the TLA and the ATs now access the same verbs as are in the ILOs, the chances are increased that most students will engage with the appropriate verbs. This is by definition a deep approach" [p. 106].
Table 1. The Alignment Between ILO, TLA And AT

\begin{tabular}{|c|l|l|l|}
\hline $\begin{array}{c}\text { Graduate } \\
\text { attribute }\end{array}$ & \multicolumn{1}{|c|}{ ILO } & \multicolumn{1}{|c|}{ TLA } & \multicolumn{1}{c|}{ AT } \\
\hline $\begin{array}{c}\text { Technology } \\
\text { competence }\end{array}$ & $\begin{array}{l}\text { Use } \\
\text { information } \\
\text { technology } \\
\text { (Ms Excel) to } \\
\text { support } \\
\text { decision } \\
\text { making in } \\
\text { an audit } \\
\text { engagement }\end{array}$ & $\begin{array}{l}\text { Through } \\
\text { Learning, } \\
\text { students use } \\
\text { technology } \\
\text { (Ms Excel) to } \\
\text { support } \\
\text { decision } \\
\text { making in } \\
\text { assessed on } \\
\text { how well } \\
\text { students use } \\
\text { technology } \\
\text { (Ms Excel) to } \\
\text { support } \\
\text { an audit } \\
\text { engagement }\end{array}$ & $\begin{array}{l}\text { Students are } \\
\text { making in } \\
\text { an audit } \\
\text { engagement }\end{array}$ \\
\hline
\end{tabular}

\section{METHOD}

The research took place in auditing classrooms in a state university in Indonesia. The research design combined both the quantitative (experiment) and the qualitative (interview) methods [40]. The study has granted an ethics approval (HRE2018-0499) from the Human Research Ethics Committee. Prior to the conduct of the study, we created an aligned system in the auditing course as described above. We recruited participants for the study through an announcement in the accounting department website, which yielded 179 third-year undergraduate accounting students who voluntarily agreed to participate in the study. Participants were randomly clustered by the university enrolment system into four classrooms, two were assigned as the experiment group and the others were assigned as the control group. Both groups possessed similar demographic characteristics such as gender and age.

Before the participants were exposed to the intervention, a test was administered to both groups. The test instrument was adapted from the case study by Andiola et al. [32] that focusses on auditing accounts receivable. The case asked students to utilize to complete electronic audit documentation, also known as audit workpapers. In order to promote teamwork skills, students worked in a group of two or three during the test. So, there were 88 total data sets from the test: 44 data were from the experimental group and 44 data were from the control group.

Then the participants in the experiment group received the treatment: studying auditing in a constructively aligned system for six weeks, while participants in the control group studying in the traditional teaching learning practice that did not 
accommodate an aligned system. The experiment and control groups were taught by the same instructor. At the beginning of the project, students in the experimental group were made aware of the learning outcomes of the course, which is to be able to use technology to support decision making in an audit. Depending on the level of complexity of the case studies, students in the experiment group typically completed the cases within one or two class meetings. In each completion of the case study, we provided feedback (formative assessment) so that students could understand which part they needed to focus on for improvement.

After the intervention, both groups were reassessed with the same test instruments taken earlier in the Pretest. The scores of the tests were compared and analysed using $\mathrm{T}$-test to measure the difference within and between groups. To complement the result of the experiment, eight students who received the intervention were interviewed in a group interview. Students were asked about their experience learning auditing in a course that has been redesigned into a more technology orientation. The group interview was audio recorded and transcribed. Thematic analysis [41] was used to analyse the interview data by generating coding and themes to reveal overarching patterns in the qualitative data.

\section{FINDINGS}

\subsection{Treatment Effect}

The results of the Pre-test and Post-test are depicted in table 2. Students in both groups performed at a low level of technology competence during the Pre-test. The students in the experiment group got an average score of 3.41 which was higher than that of the control group (1.25). We ran an independent sample t-test to examine the difference between two groups. Since we found the result was not significantly different ( $\mathrm{p}$-value $0.10>\alpha$ $0.05)$, we are confident that the random assumption between groups was validated.

After receiving exposure to constructive alignment, students' performance in the experiment group improved, as shown by the mean score of 40.91. The difference in Pre-test and Post-test means was statistically significant ( $\mathrm{p}$-value $0.00<\alpha 0.05$ ). For the control group, the mean on the Post-test was 18.41, indicating an increase from Pre-test to Post-test of 17.16. This difference in means was also statistically significant (p-value $0.00<\alpha 0.05$ ).

To test the difference of means between groups, we ran the independent sample t-test for the Post-test and found that the improvement of the experiment group was significantly higher than that of the control group. The pvalue of difference between groups was 0.00 which is less than alpha 0.05 , indicating a significant effect of constructive alignment to improve students' technological competence.

Table 2. Results of Pretest and Posttest

\begin{tabular}{|l|l|l|l|}
\hline \multicolumn{2}{|l|}{ Condition } & $\begin{array}{c}\text { Pre- } \\
\text { test }\end{array}$ & $\begin{array}{c}\text { Post- } \\
\text { test }\end{array}$ \\
\hline \multirow{2}{*}{$\begin{array}{l}\text { Experiment } \\
\text { Group } \\
N=44\end{array}$} & Mean & 3,41 & 40.91 \\
\cline { 2 - 4 } & SD & 7.76 & 23.73 \\
\cline { 2 - 4 } & $\begin{array}{l}\text { Difference in means } \\
\text { (increase) }\end{array}$ & 37.5 \\
\cline { 2 - 4 } & p-value (one-tailed) & 0.00 \\
\hline \multirow{3}{*}{$\begin{array}{l}\text { Gontrol } \\
\text { Group }\end{array} 44$} & Mean & 1.25 & 18.41 \\
\cline { 2 - 4 } & SD & 4.05 & 19.67 \\
\cline { 2 - 4 } & $\begin{array}{l}\text { Difference in means } \\
\text { (increase) }\end{array}$ & 17.16 \\
\cline { 2 - 4 } & p-value (one-tailed) & 0.00 \\
\hline \multirow{3}{*}{$\begin{array}{l}\text { Between } \\
\text { groups }\end{array}$} & Difference in means & 2.15 & 22.5 \\
\cline { 2 - 4 } & p-value & 0.10 & 0.00 \\
\hline
\end{tabular}

\subsection{Findings on Group Interview}

In a group interview of 8 students, students were asked for their perception of learning Excel in the redesigned course. Three main themes emerged from the qualitative data analysis: students' motivation to learn, students' expectation mismatch, and problem to learn.

1) Students motivation to learn: authentic learning, course alignment, and feedback

Students indicated that they were motivated to learn because they engaged in authentic learning through developing electronic audit workpapers. It is the use of case-based learning TLA that brings the new perspective of auditing practice to them.
-It is totally different from what I know about auditing in the previous auditing course. I like to practice making audit workpaper from the case study in this course.
-I can directly apply to make electronic workpaper on the given assignment in the case study.
-I am familiar with Excel, but I just know that we can utilise Excel to make electronic workpaper from the case study

Other students commented that they were motivated to learn as a result of clarity of the ILO and TLA that support the ILO.

-I learn because I know what the expectation is and what the benefit of learning this 
-I think my ability to use Excel in auditing is improved because we regularly work with auditing case studies.

Students recognized the link between ILO, TLA, and assessment to support their learning, and they became very excited to work with real auditing cases. However, they felt that the improvement of their technology competence was mostly due to the feedback they received after each assessment task. The following excerpt shows how students put effective feedback as the major catalyst for them to learn and to develop their competence.

-I can use Excel properly in the case study because of the feedback that has been given to me.

-In the beginning, I was so confused about how to make electronic workpaper in Excel, and then, fortunately, there were discussions in each assignment, so it helps me understand step by step.

-I received feedback that was quite clear to me. So, I knew how to do better in the next assignment.

-I did the first audit assignment with a very basic effort, just like what I did to any other assignment from other courses. But then I got feedback for the assignment. Since I know that I will get immediate feedback for the assignment, I give my best effort to do the assignment. I do not want to make failure twice.

\section{2) Students expectation mismatch}

Although overall students reported that they had developed their technology competence, they strongly expressed their preference to learn more specialized audit software, other than Excel.

-Well, to be honest, I want to be taught about the kind of technology in auditing. Certainly, it is not Excel.

-I want to use specific software in an audit. Just like SPSS for statistics, or MYOB for financial accounting, I want to be able to use auditing software.

-I was thinking, why Excel? There is some auditing software out there. Why did not we try one?

-I expect that I can use more specialized auditing software instead of Excel

-My expectation is to be able to use auditing software. Using excel, although for a different purpose here, is not what I expected

\section{3) Problem to learn: high volume of content}

Students felt that it was quite challenging for them to learn deeper about some technical aspects of technology since they were overloaded with a high volume of content in the courses during the semester. One comment from a student reflecting the general view: "I have 8 courses to complete this semester, and all have different topics and commitments. It is hard for me to learn everything comprehensively. Unless the lecturer gives me an assignment, I will not put an effort to learn something”.

\section{DISCUSSION}

The Auditing profession relies heavily on the use of technology, and as a consequence auditing education should accommodate technology in its curriculum. While accounting bodies such as IAESB, AICPA, and AAACSB has provided a minimum standard for students to graduate, they do not specify the strategies to accomplish that standard. This study takes the initiative to offer guidance for incorporating technology into auditing course design. The main objective of the study is to examine the efficacy of redesigning a course using constructive alignment to develop students' technological competence.

The evidence in this study confirms that the treatment does help students improve their performance to complete electronic audit workpapers. Students in the experiment group develop better technological competence than students in the control group. The finding indicates that redesigning the course through constructive alignment has a positive impact on students learning outcomes, consistent with the results of other Constructive Alignment studies [42, 43].

Our experience suggests that the alignment of ILO, TLA, and AT provides a good system for educators and students to engage in meaningful activities to achieve learning outcomes. However, the alignment is not sufficient unless effective feedback occurs within the system. Effective feedback is the key requirement for fostering the constructivist part of the learning. Prior studies also highlighted the value of feedback as an addin to the alignment system that positively affects students' approach to learning [42, 44].

Even though a significant difference in improvement between groups is apparent from this study, it is evident that the students' performance in the experimental group remains low, as indicated by the mean Post-test score of 40.91 out of 100 . This unexpected level of performance to some extent supports the notion that incorporating technology into curriculum is challenging. There are some plausible explanations for this.

First, comments by the group interview participants advocated the need to manage the topics within each course carefully. Students experienced difficulty learning deeply because they were overloaded with courses and topics covered within each course. Accounting curriculum, as well as its sub-disciplines such as auditing and taxation, is already crowded [25]. Accounting 
educators feel it is difficult to add more topics, such as technology. The same argument was from Hossain et al. [26] and Willis [20] who stated that the vast amount of theoretical content in accounting is a real challenge to customise the curriculum. While the decision to compile the course sequence in the accounting curriculum is the responsibility at the Faculty level, educators in each course could choose topics that are most relevant to teach. Biggs and Tang [9] advise us that "the greatest enemy of understanding is coverage...If you're determined to cover a lot of things... they (students) haven't had time enough to go into things in depth, ... and be able to perform that understanding in different situation" [p.43].

Second, students' expectation mismatch emerged from the qualitative data analysis. Students underestimate the potential use of Excel in Auditing, resulting in less enthusiasm to learn the utilization of technology. Students in this study are familiar with Excel, but they are not familiar with using Excel in Auditing practice, as evidenced by the Pre-test scores. This is similar to the study by Willis [20], who noted that students tend to overconfidence in their Excel proficiency, which in an employers' point of view seems lacking $[12,13,23]$. While there is some specific auditing software that have been recognized by the students in this study, recent research continues to show that Excel is utilized by most auditors [11, 16, 18]. AICPA has also added Microsoft Excel as an analysis tool in the current CPA (Certified Public Accountant) exam [45], indicating that the competency to use Excel is important to become a CPA. Further, in a study investigated the use of audit software GAS (Generalized Audit Software) by Indonesian audit firms, it was found that the use of GAS was very limited in Indonesia [46]. Despite the less frequent utilization of specialised audit software, literature has advocated the need to expose auditing students to audit software such as IDEA and ACL due to its power in analyzing larger and complex data $[10,39]$. Our recommendations to boost students' motivation to learn technology, in this case, are twofold: continue using Excel and consistently re-stress the purpose and benefit of Excel in Auditing environment, or start introducing a specialised audit software. Given the amount of time and cost consequences to introduce new software, auditing instructors may follow Sledgianowski, Gomaa, and Tan [47] and Pelzer and Delaurell [48] suggestion on a low-cost solution to incorporate auditing software into auditing curriculum. Their suggestion is to select auditing textbooks that include access to software such as ACL or IDEA, creating no additional cost for accounting department or students $[47,48]$.

\section{CONCLUSION}

The present study explored the impact of redesigning an auditing course to incorporate the development of students' technological competence. Unlike other studies that focus on "which technology is needed for the accounting profession" or "how practitioners perceive the importance of technology in auditing", this study offers a suggestion for implementation, to incorporate technology into an auditing course and to provide evidence of effectiveness.

The findings indicated that redesigning the course using Constructive Alignment does improve technology competence. Some major issues related to the implementation, such as the significance of feedback, the need to manage topics/content, and the expectation of more specialized audit software has also been discussed. Considering these issues in auditing course design would be beneficial for future research.

\section{ACKNOWLEDGMENT}

The authors acknowledge financial support from the LPDP Indonesia (Indonesia endowment fund for education).

\section{REFERENCES}

[1] M. Antcliff, R. Doren, L. Harris, D. C. Hayes, A case to provide students practice in basic and advanced functions of IDEA software, AIS Educator Journal, Colorado: AIS Educator Association and Allen Press, vol. 7(1), 2012, pp. 69-73.

[2] J. L. Bierstaker, P. Burnaby, J. Thibodeau, The impact of information technology on the audit process: an assessment of the state of the art and implications for the future, Managerial Auditing Journal, Melbourne: Emerald Publishing, vol. 16 (3), 2018, pp. 159-164.

[3] AACSB, 2018 Eligibility Procedures and Accreditation Standards for Accounting Accreditation, 2018. [Online]. Available: www.aacsb.edu, Accessed June 20, 2019.

[4] AICPA, The AICPA Pre-Certification Core Competency Framework, 2018. [Online]. Available: http://www.aicpa.org/interestareas/accountingeduca tion/resources/pages/corecompetency.aspx, Accessed June 10, 2019.

[5] IAESB, Handbook of International Education Pronouncements. New York: IFAC, 2017

[6] J. Biggs, Enhancing Teaching through Constructive Alignment, Higher Education, Switzerland: Springer Nature B.V., vol. 32 (3), 1996, pp. 347-364.

[7] J. Biggs, What the Student Does: teaching for enhanced learning, Higher Education Research \& Development, London: Informa PLC, vol. 18 (1), 1999, pp. 57-75. 
[8] J. Biggs, Constructive alignment in university teaching, HERDSA Review of Higher Education, Australia: HERDSA, vol. 1, 2014, pp. 5-22.

[9] J. Biggs and C. Tang, Teaching for Quality Learning at University, 4th ed. England: McGraw-Hill, 2011.

[10] A. Blankley, D. Kerr, C. Wiggins, An Examination and analysis of technologies employed by accounting educators, The Accounting Educators' Journal, Florida: University of Miami, vol. 28, 2018, pp. 75-98.

[11] S. Borkowski, R. Bukics, M. Welsh, Technology generation upgrades: Are educators and employers on the same page, Pennsylvania CPA Journal, Pennsylvania: PICPA, vol. 78 (3), 2007, pp. 22-27.

[12] U. R. Rackliffe and L. Ragland, Excel in the accounting curriculum: perceptions from accounting professors, Accounting Education, London: Informa PLC, vol. 25 (2), 2016, pp. 139-166.

[13] L. Ragland and U. Ramachandran, Towards an understanding of excel functional skills needed for a career in public accounting: Perceptions from public accountants and accounting students, Journal of Accounting Education, Amsterdam: Elsevier B.V., vol. 32 (2), 2014, pp. 113-129.

[14] J. Drew, Generation next, Journal of Accountancy, New York: AICPA.org, vol. 213 (6), 2012, p. 75.

[15] C. Vien, What to Know about AACSB Accounting Standard A5, 2018. [Online]. Available: https://www.journalofaccountancy.com/newsletters lextra-credit/aacsb-accounting-standard-a5.html, Accessed June 8, 2019.

[16] S. Burnett, The future of accounting education: A regional perspective, Journal of Education for Business, London: Informa PLC, vol. 78 (3), 2003, pp. 129-134.

[17] S. N., Cory and K. A. Pruske, Necessary skills for accounting graduates: An explorattory study to determine what the profession wants, ASBBS Proceedings, Las Vegas, vol. 19(1), 2012, pp. 208.

[18] L. Lee, W. Kerler and D. Ivancevich, Beyond excel: software tools and the accounting curriculum, AIS Educator Journal, Colorado: AIS Educator Association and Allen Press, vol. 13 (1), 2018, pp. 46-61.

[19] The Pathways Commission, In Pursuit of Accounting's Curricula of the Future, Florida: American Accounting Association, 2015.

[20] V. F. Willis, A model for teaching technology: Using excel in an accounting information systems course, Journal of Accounting Education, Amsterdam: Elsevier B.V.,vol. 36, 2016, pp. 87-99.

[21] D. A. Bradbard, C. Alvis, R. Morris, Spreadsheet usage by management accountants: An exploratory study, Journal of Accounting Education, Amsterdam: Elsevier B.V., vol. 32 (4), 2014, pp. 24-30.
[22] A. Jacobs, D. F. Robinson, C. A. DePaolo, Using excel to make strategic managerial decisions, Journal of Information Systems Education, Wilmington: Information Systems and Computing Academic Professionals, vol. 27 (2), 2016.

[23] W. C. Brown and B. Pike, Excel competency for the professional accountant: Advanced applications, controls, and audit add-ins, AIS Educator Journal, Colorado: AIS Educator Association and Allen Press, vol. 5 (1), 2010, pp. 25-45.

[24] M. Ojua, Accountants' perceptions of the use of excel spreadsheet in financial reporting: A survey of accounts personnel in manufacturing firms, Imperial Journal of Interdisciplinary Research (IJIR), New Delhi: IJIR vol. 2 (8), 2016, pp. 781-790.

[25] P. De Lange, B. Jackling, A. M. Gut, Accounting graduates' perceptions of skills emphasis in undergraduate courses: an investigation from two Victorian universities, Accounting and Finance, New Jersey: John Wiley \& Sons, inc, vol. 46 (3), 2006, p. 365.

[26] M. Hossain, T. Kummer, C. O’Leary, Successful implementation of written communication across an accounting degree program, SSRN, Amsterdam: Elsevier B.V., 2015.

[27] E. Boulianne, How should information technology be covered in the accounting program?, Canadian Journal of Administrative Sciences, New Jersey: John Wiley \& Sons, inc, vol. 33 (4), 2016, pp. 304 317.

[28] C. Frownfelter- Lohrke, Teaching good Excel design and skills: A three spreadsheet assignment project, Journal of Accounting Education, Amsterdam: Elsevier B.V., vol. 39, 2017, pp. 68-83.

[29] P. Bagley and N. Harp, Shoe Zoo, inc.: A practice in electronic work papers, tick mark preparation, and client communication through the audit of property, plant, and equipment, Issues in Accounting Education, Florida: Allen Press, vol. 27 (4), 2012, pp. 1131-1151.

[30] C. R. Miller and A. Savage, Vouch and trace: A revenue recognition audit simulation, Issues in Accounting Education, Florida: Allen Press, vol 24 (1), 2009, pp. 93-103.

[31] D. Peaden and N. M. Stephens, Old main manufacturing: The case of unrecorded sales discounts, Issues in Accounting Education, Florida: Allen Press, vol 28 (1), 2013, pp. 173-179.

[32] L. M., Andiola, T. A. Lambert, E. J. Lynch, Sprandel, Inc.: Electronic workpapers, audit documentation, and closing review notes in the audit of accounts receivable, Issues in Accounting Education, Florida: Allen Press, vol. 33 (2), 2018, pp. 43-55.

[33] P. L. Wessels, A critical learning outcome approach in designing, delivering and assessing the IT 
knowledge syllabus, Accounting Education, London: Informa PLC, vol. 19 (5), 2010, pp. 439-456.

[34] L. Willcoxson, M. Wynder, G. K. Laing, A wholeof-program approach to the development of generic and professional skills in a university accounting program, Accounting Education, London: Informa PLC, vol. 19 (1-2), 2010, pp. 65-91.

[35] R. A. Lawson, E. J. Blocher, P. C. Brewer, G. Cokins, J. E. Sorensen, D. E. Stout, and M. J. F. Wouters, Focusing accounting curricula on students' long-run careers: Recommendations for an integrated competency-based framework for accounting education, Issues in Accounting Education, Florida: Allen Press, vol. 29 (2), 2014, pp. 295-317.

[36] R. A. Lawson, E. J. Blocher, P. C. Brewer, J. T. Morris, K. D. Stocks, J. E. Sorensen, M. J. F. Wouters, Thoughts on competency integration in accounting education, Issues in Accounting Education, Florida: Allen Press, vol. 30 (3), 2015, pp. 149-171.

[37] J. P. Fouché, A renewed call for change in accounting education practices, International Journal of Educational Sciences, London: Informa PLC, vol. 5 (2), 2013, pp. 137-150.

[38] IAESB, Handbook of International Education Pronouncements. New York: IFAC, 2017.

[39] A. Reinstein, N. T. Churyk, S. L. Tate, Analyzing pedagogical approaches used in second auditing courses, Advances in Accounting, Amsterdam: Elsevier B.V., vol. 42, 2018, pp. 110-124.

[40] J. W. Creswell, Research Design: Qualitative, Quantitative, and Mixed Methods Approaches, 2nd ed, Thousand Oaks, California: Sage, 2003.
[41] V. Braun and V. Clarke, Using thematic analysis in psychology, Qualitative Research in Psychology, London: Informa PLC, vol. 3 (2), 2006, pp. 77-101.

[42] M. McCann, Constructive alignment in economics teaching: A reflection on effective implementation, Teaching in Higher Education, London: Informa PLC, vol. 22 (3), 2017, pp. 336-348.

[43] X. Wang, Y. Su, S. Cheung, E. Wong, T. Kwong, An exploration of Biggs' constructive alignment in course design and its impact on students' learning approaches, Assessment \& Evaluation in Higher Education, London: Informa PLC, vol. 38 (4), 2013 , pp. 477-491.

[44] L. Treleaven and R. Voola, Integrating the development of graduate attributes through constructive alignment, Journal of Marketing Education, , Thousand Oaks, California: Sage, vol. 30 (2), 2008, pp. 160-173.

[45] C. Baysden, How Tax Reform - and Excel - are changing the CPA Exam, 2018, [Online] Available: https://www.journalofaccountancy.com/podcast/cp a-exam-changes-tax-reform-excel.html, Accessed June 10, 2019.

[46] R. Widuri, Adoption and use of generalized audit software by Indonesian audit firms, unpublished

[47] D. Sledgianowski, M. Gomaa, C. Tan, Toward integration of Big Data, technology and information systems competencies into the accounting curriculum, Journal of Accounting Education, Amsterdam: Elsevier B.V.,vol. 38, 2017, pp. 81-93.

[48] J. Pelzer and R. Delaurell, Implementation of AACSB Standard A7: A Strategy for Limited Resources, The Accounting Educators' Journal, Florida: University of Miami, vol. 28, 2019. 